Wiesław T. Stefańczyk

Uniwersytet Jagielloński, Kraków

reinhold5@interia.pl

\title{
ZMIANY WE WSPÓŁCZESNYM POLSKIM SYSTEMIE FLEKSYJNYM (NA MATERIALE RZECZOWNIKOWYM I PRZYMIOTNIKOWYM)
}

Słowa klucze: rzeczownik, końcówka fleksyjna, zmiany językowe, przymiotnik Keywords: noun, inflective suffix, language changes, adjective

Celem artykułu jest wskazanie dokonujących się zmian w polskiej fleksji imiennej. Rozważania dotyczą głównie rzeczownika, w mniejszym zakresie również przymiotnika. Podstawę materiałową stanowią dwa źródła leksykograficzne: Słownik jezzyka polskiego pod red. Witolda Doroszewskiego (SJPD) oraz Uniwersalny słownik języka polskiego pod red. Stanisława Dubisza (USJP). SJPD oprócz leksyki współczesnej uwzględnia również jej starszą warstwę, natomiast USJP zawiera słownictwo zasadniczo współczesne. Taki dobór źródeł pozwala prześledzić zmiany jakościowe i ilościowe w zakresie polskiej fleksji i dokonać ich analizy porównawczej. Badaniom poddano łącznie ok. 70 ooo rzeczowników i ok. 25000 przymiotników zawartych w SJPD oraz ok. 45 ooo rzeczowników i ok. 19 ooo przymiotników uwzględnionych w USJP. Różnice ilościowe w obu badanych źródłach wynikają głównie $\mathrm{z}$ faktu, że SJPD - w przeciwieństwie do USJP - zawiera wiele archaizmów, wyrazów przestarzałych, gwarowych bądź charakteryzujących się indywidualnym użyciem, a także znaczną część niezleksykalizowanych rzeczowników odczasownikowych. Szczegółowe dane liczbowe dotyczące struktury słownictwa zawartego w SJPD przedstawił Zygmunt Saloni (1988a). W niniejszym artykule stosowany jest tradycyjny podział rzeczowników na rodzaje gramatyczne na podstawie postaci mianownika obu liczb. 
Z przeprowadzonych badań wynika, że najwięcej zmian jakościowych w zakresie fleksji polskiego rzeczownika występuje w trzech najczęściej używanych przypadkach, tj. w mianowniku, dopełniaczu i bierniku. W pozostałych przypadkach natomiast ograniczają się one do kilku izolowanych form.

Jedną z najbardziej ewidentnych zmian w zakresie odmiany rzeczownika w mianowniku jest recesywny charakter męskoosobowej końcówki -owie (por. też np. Satkiewicz 1981; Dubisz 1995; Krzyżanowski 2013a). Jej funkcję przejmuje zakończenie $-i / /-y$, stąd dawne formy typu redaktorowie, rektorowie, ordynatorowie, autorowie, dyrektorowie, dziekanowie mają obecnie niemal wyłącznie postać redaktorzy, rektorzy, ordynatorzy, autorzy, dyrektorzy, dziekani. Proces wypierania końcówki -owie jest nadal żywy i obejmuje ustawicznie nowe leksemy, np.: patron, opiekun, ambasador, profesor, mające również postać patroni, opiekuni, ambasadorzy, profesorzy. Pierwotne semantyczne reguły doboru końcówki -owie są obecnie mocno rozchwiane, zarówno bowiem rzeczowniki oznaczające stopień pokrewieństwa, jak i nazwy osób zajmujących prestiżowe stanowiska w hierarchii społecznej mają różne zakończenia, np.: rodzice, rodziciele, siostrzeńcy, bracia, kuzyni, konkubenci; papieże, cesarze, kanclerze, prezydenci, premierzy, rektorzy. Z drugiej natomiast strony rzeczowniki nieoznaczające godności i tytułów mogą mieć końcówkę -owie, np. stróżowie, pasażerowie, majstrowie, bacowie, w tym nacechowane, np.: pijaczkowie, opryszkowie. Zakończenie -owie ogranicza współcześnie swój zasięg do rzeczowników z sufiksem -ek, quasi-złożeń z członem archa, leksemów z wygłosowym $f$ oraz $k$, np.: świadkowie, bratankowie, monarchowie, oligarchowie, filozofowie, szefowie, posłowie, generałowie. Do recesji końcówki -owie przyczynia się być może również fakt, że jest ona dwusylabowa, a więc nieekonomiczna (por. też Satkiewicz 1981).

Drugą istotną zmianą jest wzrost liczby rzeczowników męskoosobowych, mających obowiązkowo bądź obocznie końcówki niemęskoosobowe, np.: chamy, łobuzy, lizusy, łakomczuchy. Implikują je czynniki semantyczne, tj. nacechowanie rzeczownika oraz kryterium słowotwórcze, o czym świadczą derywaty z sufiksami -ch, -uch, -och, -as, -os, -us, mające niemal wyłącznie niemęskoosobową końcówkę -y, np.: komuchy, piecuchy, pieszczochy, głuptasy, młokosy, lizusy (por. też Saloni 1988b; Dunaj 1992). Z obliczeń sporządzonych na podstawie USJP wynika, że ok. 11\% rzeczowników męskoosobowych ma w mianowniku liczby mnogiej końcówki niemęskoosobowe. Do wzrostu liczby tego typu form przyczynia się w znacznym stopniu zmiana semantyki formantów. Potwierdza to zwłaszcza sufiks -ak, częściowo też -ek, derywujące w ciągu ostatnich dziesięcioleci wyrazy należące do języka potocznego i substandardowego, implikujące w konsekwencji obowiązkowo bądź fakultatywnie końcówkę niemęskoosobową, np.: tajniacy - tajniaki, partyjniacy -partyjniaki, prostacy - prostaki, pierwszaki, dzieciaki, bydlaki (por. Grzegorczykowa, Puzynina 1998: 420). Część rzeczowników z niemęskoosobową końcówką typu chłopaki, wnuki zatraciła swe dawne nacechowanie (por. też Dunaj 1992). Odrębne zagadnienie stanowią formy deprecjatywne typu profesory, chłopy, dziadki. Ich 
bliższe omówienie nie jest jednak możliwe, ponieważ analizowane źródła uwzględniają postaci standardowe.

Do pozostałych zmian w zakresie odmiany rzeczownika w mianowniku (bierniku) należy zastępowanie końcówki -e zakończeniem - $y$ w grupie zapożyczeń z języka francuskiego na -ons, -ans, stąd oboczności typu ambulanse - ambulansy, pasjanse pasjansy, bilanse - bilansy, mezalianse - mezaliansy, romanse - romansy, rekonesanse - rekonesansy (por. też Satkiewicz 1981; Krzyżanowski 2013a). Jest to jednak grupa nieliczna, tworzy ją bowiem jedynie ok. 20 leksemów, a wskazane zmiany obejmują w standardowej polszczyźnie jedynie kilka z nich. W języku potocznym następuje dalszy proces uproszczeń, stąd postaci typu kwadransy, konwenansy.

Z przeprowadzonych badań wynika, że dawna końcówka - $a$, występująca pierwotnie w wyrazach obcego pochodzenia typu dokument, pakt, grunt, koszt, inspekt została wyparta przez regularne zakończenie $-y$, stąd niemal wyłączne formy typu dokumenty, pakty, grunty, koszty, inspekty. Jedynym rzeczownikiem otrzymującym końcówkę - $a$ jest leksem akt 'dokument', choć dopuszczalna jest także postać z końcówką $-y$.

W dopełniaczu liczby pojedynczej rodzaju męskiego w grupie rzeczowników nieżywotnych współwystępują dwie końcówki równoległe: dominująca -u, którą otrzymuje ok. 70\% leksemów, oraz rzadsza - $a$, którą przybiera ok. 30\% leksemów (por. Stefańczyk 2007: 82-86). Nowo przyswojone wyrazy mają obecnie zarówno zakończenie -u, np.: internetu, bankomatu, telebeamu, mobbingu, overdraftu, wpłatomatu, klipu, jak i -a, np.: skanera, absorbera, desorbera, bloga, e-maila. Należy podkreślić, że „ekspansja” końcówki - $a$, na którą zwracają uwagę językoznawcy (por. np. Krzyżanowski 2013a), jest w istocie procesem wyrównawczym, obejmującym od dawna rzeczowniki zakończone na -ek, -er, -us oraz -el (por. Grappin 1956: 10-25; Westfal 1956; Stefańczyk 2007: 50-86). Potwierdza to liczna grupa rzeczowników typu urywek, docinek, bunkier, neseser, chaber, bestseller, folder, obrus, cytrus, mo$d z e l$, w których pierwotne zakończenie - $u$ jest zastępowane końcówką - $a$. Dawne reguły semantyczne nie przystają $\mathrm{w}$ pełni do synchronicznego opisu dystrybucji końcówek dopełniacza. Wyodrębniane przez językoznawców klasy rzeczowników, jak np. nazwy części ciała czy nazwy narzędzi, mogą mieć zarówno końcówkę - $u$, jak i -a, np.: grzbietu, przełyku, gruczołu, mózgu, narządu, szpiku, karku - łokcia, paznokcia, palca, nadgarstka, żoładka, mostka, obojczyka; bankomatu, parkomatu, samochodu, samolotu, przycisku, dźwigu, kastetu - młotka, komputera, wieszaka, czerpaka, pilnika, silnika, hamulca. Z badań wynika, że o użyciu końcówki -a decydują najczęściej czynniki morfologiczne, tj. jakość sufiksacji, rzadziej kryterium semantyczne (por. biernik) i fonetyczne. Derywaty sufiksalne, tworzące jakościowo wspólną klasę słowotwórczą z rzeczownikami żywotnymi, mają końcówkę - $a$, np.: tętniaka - rybaka, podbródka - podlotka, budzika - ludzika, piórnika - kierownika, całusa - dzikusa, skanera - prezentera, spinacza - biegacza, lipca - chłopca, w tym także rzadkie i izolowane, np.: bieguna - opiekuna, kikuta - mańkuta. Czynniki 
fonetyczne implikują końcówkę - $a$ w grupie rzeczowników miękkotematowych, np.: jęczmienia, kamienia, gwoździa, łokcia, chlebusia.

Istotną zmianą $\mathrm{w}$ zakresie odmiany rzeczownika $\mathrm{w}$ dopełniaczu liczby mnogiej jest ograniczenie użycia końcówek -ów oraz - w grupie leksemów o tematach stwardniałych i miękkich wszystkich rodzajów gramatycznych, stąd dawne formy pisarzów, komeż, łącz mają obecnie postać pisarzy, komży, łaczy (por. też Dubisz 1995, Krzyżanowski 2013a). Proces ten prowadzi do dwu istotnych uproszczeń:

1. rzeczowniki wszystkich rodzajów gramatycznych o tematach stwardniałych i miękkich mają jedną wspólną końcówkę -i//-y, np.: stuchaczy, pryczy, łączy, górali, dziupli, przedszkoli;

2. dopełniacz liczby pojedynczej rzeczowników rodzaju żeńskiego o tematach stwardniałych i miękkich jest (staje się) synkretyczny z dopełniaczem liczby mnogiej, np.: mszy, gondoli, kolacji.

W języku potocznym następuje dalszy proces zmian wyrównawczych, stąd formy typu meczy, cywili, zorzy. Wskazanym prawidłowościom nie podlegają rzeczowniki z wygłosowym $c$, choć istnieją formy wariantywne typu materaców - materacy, derywaty z sufiksem -ini//-yni oraz derywaty odczasownikowe na -anie, -enie, -cie.

Do pozostałych zmian w odmianie rzeczownika w dopełniaczu (bierniku) należy powolny proces wycofywania się końcówki -ów na rzecz dominującego ilościowo zakończenia - $\varnothing \mathrm{w}$ grupie rzeczowników zakończonych na -anin, stąd formy wariantywne typu wegetarianów - wegetarian, weganów - wegan, marianów - marian, prezbiterianów - prezbiterian, oratorianów - oratorian. Końcówka -ów utrzymuje się nadal w grupie rzeczowników z tematycznym $-k$, np. franciszkanów, dominikanów, anglikanów, republikanów, choć i tu występują postaci wariantywne, np. Meksykanów - Meksykan oraz formy z końcówką -, np. Korsykan.

W bierniku liczby pojedynczej rodzaju męskiego od kilku stuleci obserwuje się wzrost liczby rzeczowników nieżywotnych mających męskożywotną końcówkę - $a$. Badacze odnotowują od 300 (Kucała 1970) do ponad 1000 tego typu form (Bańko 2002: 153). USJP rejestruje ponad 400 tego typu leksemów, co stanowi ponad 4\% ogółu rzeczowników nieżywotnych. Nie jest to liczba kompletna, słownik nie uwzględnia bowiem między innymi nazw firmowych i gatunkowych typu ford, volkswagen, philips, camel. Z badań wynika, że końcówkę - a implikują czynniki zarówno semantyczne, jak i morfologiczne. Kryterium znaczeniowe obejmuje następujące grupy rzeczowników: nazwy grzybów, np.: borowika, maślaka, muchomora; nazwy jednostek monetarnych, np.: funta, lira, forinta; nazwy ciał zmarłych, np.: trupa, denata, umrzyka; większość policzalnych nazw pokarmu, np.: gołabka, paczka, ziemniaka; niektóre nazwy kwiatów, np.: bratka, tulipana, narcyza; nazwy rodzajowe, gatunkowe, firmowe tańców, np.: oberka, poloneza, czardasza; gier karcianych, np.: brydża, pokera, tysiąca; gier i zabaw, np.: berka, tenisa, palanta; papierosów, np.: carmena, camela, chesterfielda; środków transportu, np.: opla, volkswagena, boeinga; a także nazwy innych wyrobów przemysłowych, np.: samsunga, philipsa, chanela (por. 
też Swan 1988; Riley 1999; Bańko 2002: 151-152; Stefańczyk 2007: 89-92). Kryterium słowotwórcze obejmuje część derywatów z sufiksami: -as, -os, -us, -ch, -uch, -osz, $-o l,-i n / /-y n,-a k,-e c,-i s z / /-y s z$, w tym także derywaty odrzeczownikowe wsteczne oraz złożenia z członem man, np.: zakrętasa, papierosa, całusa, papierocha, palucha, grubosza, patola, wegrzyna, krwiaka, szturchańca, złocisza, kopa, kaca, walkmana, discmana (por. Swan 1988; Riley 1999; Stefańczyk 2007: 89-92). Jest to proces nadal żywy, o czym świadczą nowo zaadaptowane wyrazy typu blog, facebook, przybierające końcówkę - $a$. Jego konsekwencją jest wzrost synkretyzmu biernika i dopełniacza liczby pojedynczej, biernik rzeczowników nieżywotnych nie jest też już zwierciadlanym odbiciem mianownika.

Pewne zmiany występują również w zakresie odmiany rzeczownika w bierniku liczby mnogiej, mianowicie biernik nie zawsze jest synkretyczny $\mathrm{z}$ dopełniaczem, istnieje bowiem pewna grupa rzeczowników męskoosobowych mająca końcówki niemęskoosobowe, np. dzieciaki, bobasy, bobaski, maluchy, maluszki, niemowlaki, noworodki, brzdace, berbecie, bajtle (por. Tokarski 2001).

Omawiane procesy wyrównawcze występują także w pozostałych przypadkach, gdzie obejmują jednak niewielkie liczebnie grupy leksemów.

W celowniku liczby pojedynczej rodzaju męskiego obserwuje się dalszy proces wypierania końcówki - u przez dominujące ilościowo zakończenie -owi, stąd formy wariantywne: człeku - człekowi, katu - katowi, diabłu-diabłowi, czartu-czartowi, osłu - osłowi, orłu - orłowi. Końcówka - $u$ utrzymuje się nadal w grupie 13 rzeczowników o wysokiej frekwencji: Bogu, panu, ojcu, księdzu, światu, bratu, kotu, psu, lwu, wołu, chłopu, chłopcu, księciu.

Podobny proces występuje w narzędniku liczby mnogiej, gdzie ustawicznie wypierana jest historyczna końcówka - mi przez dominujące zakończenie -ami, stąd dawne formy typu gęśmi, gałęźmi, gwoźdźmi są zastępowane przez postać z końcówką -ami (por. Dubisz 1995; Krzyżanowski 2013a). O żywotności tego procesu świadczą obecnie leksemy skroń i kiść, a także neosemantyzmy typu gość 'facet' czy zestawienie stary koń, mające zakończenie -ami, choć zarówno leksem gość, jak i koń utrzymują historyczną postać z końcówką -mi. Zakończenie - mi występuje ponadto w formach: przyjaciólmi, pieniędzmi, ludźmi, dziećmi, nićmi, księżmi, braćmi, liśćmi, kośćmi.

W zakresie odmiany rzeczownika w wołaczu rodzaju męskiego obserwuje się dalszy wzrost synkretyzmu z miejscownikiem w grupie leksemów zakończonych na -ec (por. też Dubisz 1995). Potwierdzają to formy typu sportowcu, kupcu, malcu, komsomolcu, koślawcu, skubańcu, a także postaci wariantywne typu szubrawcu szubrawcze. Końcówkę - e otrzymuje nadal ok. 100 rzeczowników zakończonych na -ec, w tym leksemy o wysokiej frekwencji, np.: ojcze, chłopcze, młodzieńcze.

Wskazanym zmianom jakościowym towarzyszy ustawiczny wzrost liczby rzeczowników nieodmiennych. SJPD uwzględnia 227 indeklinabiliów, natomiast USJP ponad dwukrotnie więcej, tj. 480, co stanowi ponad 1\% ogółu leksemów rzeczow- 
nikowych. Analizowane źródła nie uwzględniają pełnej listy rzeczowników nieodmiennych, brak w nich bowiem leksemów typu chaczapuri, ravioli, tiramisu. Grupę indeklinabiliów tworzą oprócz nielicznych rzeczowników rodzimych typu papu, widzimisię, ladaco głównie wyrazy obcego pochodzenia, np.: safari, alibi, bikini, hobby, igloo, judo, euro, exposé, atelier, haiku, tabu, kipu. Rzeczowniki te poza nielicznymi leksemami o wygłosie spółgłoskowym typu katharsis, imprimatur są na ogół zakończone na samogłoski: $-e,-i / /-y,-o,-u$, np.: biennale, triennale, alibi, safari, lobby, InterCity, espresso, euro, tabu, rendez-vous, co implikuje rodzaj nijaki (por. Stefańczyk 2007: 44-46; Przybylska 2010; Krzyżanowski 2013b). Jedynie rzeczowniki o znaczeniu osobowym mają rodzaj męski, np.: macho, guru, lub żeński, np.: lady, miss, o czym decyduje rodzaj naturalny. Należy zaznaczyć, że część tego typu rzeczowników, jak kakao, wideo, logo, w polszczyźnie potocznej ma postaci fleksyjne.

Drugą grupę indeklinabiliów tworzą rzeczowniki rodzaju męskiego oznaczające zawody, tytuły, godności typu kupiec, inżynier, agronom, profesor, doktor używane w stosunku do kobiet. W związku z brakiem wielu feminativów we współczesnej polszczyźnie funkcję formy żeńskiej pełni rodzaj męski. Rzeczowniki te poza postacią narzędnika w orzeczeniu imiennym, np. Pani Anna Nowak jest dyrektorem, są nieodmienne w obu liczbach (por. też Satkiewicz 1981). W języku potocznym orzecznik w tego typu konstrukcjach bywa wyrażany również mianownikiem.

Liczną grupę rzeczowników nieodmiennych stanowią ponadto nazwy własne typu Chicago, Toronto, Oslo, Tbilisi, Calgary, Baku, a także nazwiska kobiet, np.: Nowak, Satkiewicz, Butler, Wolny. Badany materiał nie uwzględnia jednak zasadniczo materiału onomastycznego, nomina propria nie mogą więc być przedmiotem niniejszych rozważań.

Zmiany ilościowe obejmują ponadto następujące grupy leksemów: rzeczowniki rodzaju żeńskiego o wygłosie spółgłoskowym funkcjonalnie miękkim i miękkim, rzeczowniki rodzaju męskiego i żeńskiego o wygłosie labialnym twardym, pierwotnie miękkim, rzeczowniki rodzaju nijakiego zakończone na -ę, rzeczowniki rodzaju nijakiego o znaczeniu zbiorowym, pluralia tantum oraz rzeczowniki o odmianie przymiotnikowej.

Rzeczowniki rodzaju żeńskiego o wygłosie spółgłoskowym stwardniałym i miękkim tworzą grupę 155 leksemów (SJPD uwzględnia ok. 180), co stanowi niespełna $0,5 \%$ ogółu rzeczowników (liczba ta nie obejmuje rzeczowników rodzaju żeńskiego zakończonych na -(o)ść). Z synchronicznego punktu widzenia rzeczowniki te są nietypowe dla rodzaju żeńskiego, swą postacią fonetyczną i morfologiczną przypominają bowiem leksemy rodzaju męskiego, por. sól - mól, ciecz - miecz, noc - koc, sień - cień, kolej - olej. Z tego względu część z nich wyrównuje swą postać do dominujących ilościowo femininów zakończonych na -a, czemu towarzyszy zmiana paradygmatu odmiany. Dokonuje się to za pomocą końcówki - $a$, sufiksu -ka lub -ina, np.: karuzel>karuzela, stokroć>stokrotka, zmarzłoć>zmarzlina (por. potoczne formy mysza, wsza). Część tego typu rzeczowników, zachowując 
swą postać fonetyczną i morfologiczną, zmienia rodzaj gramatyczny na męski, np.: goleń, piszczel (por. dawne feminina typu piec, cień). Istnieją także przykłady poświadczające zmianę rodzaju na nijaki, np.: naręcz>naręcze, zarośl $>$ zarośle, suchorośl>suchorośle.

Rzeczowniki o wygłosie wargowym twardym, pierwotnie miękkim są kategorią recesywną. USJP uwzględnia jedynie ok. 40 tego typu leksemów (SJPD rejestruje ok. 50), np.: gołab, karp, modrzew, paw, szczaw, krew, cerkiew, brukiew, rzodkiew, brew, w tym wyrazy przestarzałe, np.: stagiew, panew, konew. Część rzeczowników rodzaju męskiego, nie zmieniając swej postaci fonetycznej i morfologicznej, odmienia się według wzorca twardego, np. głab - głaba, potraw - potrawu (por. dawne głabia, potrawiu). Istnieją także izolowane przykłady poświadczające zmianę rodzaju męskiego na nijaki, tj. ślep>ślepie, sitow >sitowie (por. też Reichan 1975). Rzeczowniki rodzaju żeńskiego przybierają sufiks -ka lub -ina, np.: konew >konewka, panew>panewka, głąb>głębina (też głębia), czemu towarzyszy zmiana paradygmatu odmiany.

Podobnie recesywną grupę stanowią rzeczowniki rodzaju nijakiego zakończone na -ę. SJPD podaje 114 tego typu leksemów, natomiast USJP uwzględnia niemal dwukrotnie mniej, tj. 58, w tym wyrazy przestarzałe, np.: wróble, jaskółczę, łoszę. Znaczna część tego typu leksemów zanikła, np.: chałupię, człeczę, panię, capię, inne natomiast przybierają sufiks -ak, np.: dzieciak, kociak, bydlak, zachowując jednocześnie swą historyczną postać z końcówką -ę, stąd formy wariantywne typu prosięprosiak. Do zmiany postaci morfologicznej i jednocześnie rodzaju gramatycznego przyczynia się zapewne fakt, że rzeczowniki te mają dwa skomplikowane, uwarunkowane historycznie paradygmaty odmiany. Ich odmianie towarzyszy rozszerzenie tematu o-eń-, -on- w grupie rzeczowników zakończonych na -mię oraz o-ęć-, -ęt//-ąt w grupie leksemów o zakończeniu innym niż -mię. Izolowane względnie nowe tego typu formacje, co poświadcza zrost widzimisię, są nieodmienne.

Recesywne tendencje obserwuje się także w grupie rzeczowników rodzaju nijakiego o znaczeniu kolektywnym. Znaczna część tego typu leksemów, głównie derywatów z sufiksem -(o)stwo, zanikła, np.: katolictwo, luterstwo, kalwiństwo, inne natomiast, jak żydostwo, nauczycielstwo, charakteryzują się ograniczonym użyciem. Odrębną grupę stanowią rzeczowniki typu liście, rupiecie, śmiecie, starocie, które zmieniły swą postać morfologiczną i rodzaj gramatyczny, stąd obecne formy liść, rupieć, śmieć, staroć.

Konsekwencją wskazanych procesów jest ustawiczne zmniejszanie się liczby rzeczowników rodzaju nijakiego. Według USJP neutra tworzą grupę ok. 4 ooo rzeczowników (SJPD uwzględnia ok. 17 ooo), co stanowi ok. 10\% ogółu leksemów, w tym znaczna część zleksykalizowanych derywatów odczasownikowych typu śniadanie, natchnienie, napięcie.

W zakresie rzeczowników plurale tantum obserwuje się następujące tendencje:

1) Zanik znacznej części pluraliów tantum męskoosobowych, np.: miecznikostwo, chorążostwo, asesorostwo. SJPD uwzględnia 64 tego typu leksemy, natomiast 
USJP rejestruje 41. Jedynym rzeczownikiem o wysokiej frekwencji jest leksem państwo (Kurcz et al. 1990).

2) Recesywny charakter rzeczowników zakończonych na -iny//-yny, np.: zrękowiny. Teresa Friedelówna (1968), bazując na materiale z XIX i pierwszej połowy XX w., odnotowała 91 tego typu form, natomiast USJP uwzględnia jedynie 36.

3) Żywy proces depluralizacji, co potwierdzają pojedyncze leksemy rodzic, milusiński, terminy typu aktywo, pasywo, a także potoczne formy lód, spodzień, perfum (por. też Grabias 1975: 37-45; Zaręba 1983: 52-54).

Warto jeszcze zwrócić uwagę na dane liczbowe zawarte w analizowanych źródłach. SJPD uwzględnia 768 rzeczowników plurale tantum, natomiast USJP rejestruje ok. 1070. Przytoczone liczby pozornie sugerują, że wzrasta liczba tego typu leksemów. Bliższa analiza wykazuje jednak, że ok. 450 rzeczowników typu porzadki, żale, poezje, wojska, żniwa ma regularne formy obu liczb, a ich użycie w liczbie mnogiej ma charakter kontekstualny.

Zmiany ilościowe obejmują także rzeczowniki o odmianie przymiotnikowej. SJPD podaje 1500 tego typu leksemów, natomiast USJP uwzględnia ok. 580, w tym nazwy własne typu Lubelskie, Gdańskie, Poznańskie. Liczby te wyraźnie pokazują, że zanikła znaczna część rzeczowników o odmianie przymiotnikowej, są to głównie nazwy opłat, np.: mostowe, kominne, grobelne, kuchenne, inne występują obecnie jedynie w wyrażeniach, np.: na odchodne, na odjezdne. Poza izolowanymi leksemami jak becikowe nie odnotowano nowych tego typu rzeczowników.

Pewne zmiany można zaobserwować również w zakresie form przymiotnikowych. Zdecydowana większość polskich przymiotników, tj. ok. 16 ooo, ma w mianowniku liczby pojedynczej zakończenie - $y$. Grupę tę tworzą przymiotniki o tematach twardych i funkcjonalnie miękkich, np.: nowy, ładny, stary, cudzy, obcy. Regularną końcówkę - $i$ mają przymiotniki zakończone na - $k i$, -gi, np.: wysoki, niski, słodki, drogi, długi. Grupę tę egzemplifikuje ok. 2700 przymiotników, w tym jedynie 37 zakończonych na -gi. W badanym materiale odnotowano 165 przymiotników miękkotematowych, co stanowi ok. o,8\%, np.: tani, głupi, przedni, w tym nacechowane, np.: cieniusi, okraglusi, malusi, i przestarzałe, np.: herbatni. Słownik frekwencyjny polszczyzny wspótczesnej odnotowuje jedynie 28 tego typu przymiotników (Kurcz et al. 1990). W związku z frekwencją form z końcówką -y, a także leksemów zakończonych na $-k i$ przymiotniki te zmieniają swą postać morfologiczną. Potwierdzają to dawne formy typu tylni, intratni, herbatni, cyklopi, mnisi, mające obecnie postać tylny, intratny, herbaciany i coraz częściej cyklopowy, mniszy. Odrębną grupę tworzą przymiotniki typu babi, diabli, które przybrały sufiks -ski i mają obecnie regularną postać babski, diabelski, a dawna forma utrzymuje się jedynie w wyrażeniach typu babie lato.

Z przeprowadzonych badań wynika, że upraszcza się polski system fleksyjny. Zmiany jakościowe - jak wykazała analiza - obejmują trzy najczęściej używane przypadki - mianownik, dopełniacz i biernik. Procesom wyrównawczym podlegaja 
ponadto rzadkie i nieregularne z synchronicznego punktu widzenia grupy rzeczownikowe i formy przymiotnikowe. Procesom tym towarzyszy jednocześnie znaczny wzrost liczby leksemów nieodmiennych, głównie obcego pochodzenia - zarówno nazw własnych, jak i rzeczowników pospolitych, co sprawia, że zmienia się oblicze polskiej fleksji.

\section{Literatura}

BAŃKo M., 2002, Wykłady z polskiej fleksji, Warszawa.

Dubisz S., 1995, Rozwój współczesnej polszczyzny, „Przegląd Humanistyczny” z. 5, s. 69-88.

Dunaj B., 1992, Formy mianownika liczby mnogiej rodzaju męskiego we współczesnej polszczyźnie literackiej, „Język Polski” LXXII z. 4/5, s. 25-264.

Friedelówna T., 1968, Kategoria plurale tantum w języku polskim, Toruń.

Grabias S., 1975, Formacje ekspresywne typu spodzień, koszul, „Prace Filologiczne” t. XXV, S. $37-45$.

Grappin H., 1956, Histoire de la flexion du nom en polonais, Wrocław.

Grzegorczy kowa R., Puzynina J., 1998, Słowotwórstwo. Rzeczowniki, [w:] R. Grzegorczykowa, R. Laskowski, H. Wróbel (red.), Gramatyka współczesnego języka polskiego, t. 2: Morfologia, Warszawa.

KrzyŻANOWsKi P., 2013a, Zmiany we fleksji współczesnej polszczyzny, [w:] A. Dunin-Dudkowska, A. Małyska (red.), 7o lat współczesnej polszczyzny. Zjawiska - procesy tendencje, Lublin, s. 239-249.

KRZYŻANOWSKI P., 2013b, Właściwości gramatyczne rzeczowników nieodmiennych, Lublin.

KuCAŁA M., 1970, Formy dopełniacza w bierniku liczby pojedynczej rzeczowników męskich nieżywotnych, [w:] W. Krencik (red.), W stużbie nauce i szkole. Księga pamiątkowa poświęcona Profesorowi Doktorowi Zenonowi Klemensiewiczowi, Warszawa.

Kurcz I., Lewicki A.M., Szafran K., WoronczaK J. (red.), Słownik frekwencyjny polszczyzny wspótczesnej, Kraków.

PRZYBYLSKA R., 2010, Jakiego rodzaju jest zombie $i$ CD? Jeszcze raz o rodzaju gramatycznym rzeczowników zapożyczonych z języka angielskiego, "Język Polski” XC, Z. 4/5, s. 246-255.

REICHANJ.,1975,Zmianywefleksjirzeczownikówmęskichzakończonychpierwotnienaspółgłoski wargowe palatalne w jezzyku polskim na tle słowiańskim, Wrocław-Warszawa-Kraków.

Riley T.G., 1999, IT's Alive: Grammatical Animacy in Russian, Polish and Czech, Seattle.

SALONI Z., 1988a, Struktura gramatyczna słownictwa zawartego $w$ Słowniku języka polskiego PAN pod red. W. Doroszewskiego - zestawienie liczbowe, [w:] idem (red.), Studia z polskiej leksykografii współczesnej, Wrocław, s. 149-160.

SALONI Z., 1988b, O tzw. formach nieosobowych męskoosobowych we współczesnej polszczyźnie, „Biuletyn PTJ” t. LXI, s. 155-166.

SatKiewiCz H., 1981, Tendencje do ekonomiczności we fleksji wspótczesnego języka polskiego, [w:] H. Kurkowska (red.), Współczesna polszczyzna. Wybór zagadnień, Warszawa, S. $47-75$.

SJPD: W. Doroszewski (red.), Słownik języka polskiego, Warszawa 1958-1969.

StefańCZyk W.T., 2007, Kategoria rodzaju i przypadka polskiego rzeczownika. Próba synchronicznej analizy morfologicznej, Kraków. 
Swan O., 1988, Facultative Animacy in Polish. A Study in Grammatical Gender Formation. (The Carl Back in Russian and East European Studies, 606), Pittsburgh.

TOKARSKi J., 2001, Fleksja polska, Warszawa.

USJP: S. Dubisz (red.), Uniwersalny słownik języka polskiego, Warszawa 2003.

Westfal S., 1956, A Study in Polish Morphology. The Genitive Singular Masculine, Glasgow. ZaręBA A., 1983, O tak zwanej depluralizacji w języku polskim, [w:] idem, Pisma polonistyczne i slawistyczne, Warszawa-Kraków, s. 52-54.

\section{Changes in the inflectional system of Polish (an analysis of nouns and adjectives) \\ Summary}

The article deals with current tendencies and changes in the Polish inflectional system. The largest number of changes can be observed in three most frequently encountered cases: Nominative, Genitive and Accusative. Changes in the remaning cases are limited to several isolated lexemes. An important characteristic of the current inflectional system of Polish is an increase in the number of indeclinable nouns, as well as the slow disappearance of groups of rare and irregular nouns. 